\section{Osmotic Seed Priming of Rudbeckia fulgida Improves Germination and Expands Germination Range}

\author{
Amy M. Fay ${ }^{1}$, Mark A. Bennett ${ }^{2}$, and Steven M. Still ${ }^{3}$ \\ Department of Horticulture, The Ohio State University, Columbus, OH 43210
}

Additional index words. osmoconditioning, black-eyed Susan, potassium nitrate, polyethylene glycol 8000, optimal germination temperature

\begin{abstract}
Low-vigor seeds of black-eyed Susan (Rudbeckia fulgida Ait.) primed in aerated $-1.3 \mathrm{MPa} \mathrm{KNO}_{3}$ for 7 days at $30 \mathrm{C}$ in darkness had double the total germination percentage at $30 \mathrm{C}$ and one-half the mean time of germination as nonprimed seeds. Priming the seeds in polyethylene glycol rather than $\mathrm{KNO}_{3}$ generally resulted in lower total germination percentage and longer mean time of germination. Osmotic priming increased total germination percentage and germination rate of seeds germinated at 21.9 to $32.2 \mathrm{C}$, but the priming benefit on total germination percentage was greater at $\leq \mathbf{2 7 . 6 C}$. Total germination percentage of primed and nonprimed seeds was highest at 28.8 to $32.2 \mathrm{C}$.
\end{abstract}

Rudbeckia fulgida, also known as blackeyed Susan, gloriosa daisy, and orange coneflower, is a herbaceous perennial popular in urban landscapes. It possesses heat tolerance, powdery mildew resistance, desirable ornamental qualities, and a long bloom season. Current germination recommendations for Rudbeckia are varied. Suggested germination regimes include 21 to $24 \mathrm{C}$ for 14 to 21 days (George J. Ball, 1989; G.W. Park Seed Co., 1989-90; Tayama, 1989), although official germination requirements for $R$. fulgida have not been established (Association of Official Seed Analysts, 1990). Difficulty in germination and variable germination rates can cost perennial plant producers time, money, and crop loss.

Seed priming reduces the germination time for many vegetable and herbaceous perennial crops (Brocklehurst and Dearman, 1984; Finnerty et al., 1992). Osmotic seed priming, alias osmoconditioning, is a process of controlled water imbibition by the seed through the use of osmotic solutions containing polyethylene glycol (PEG) (Heydecker et al., 1975) or inorganic salts (Heydecker and Coolbear, 1977). The seeds are "primed" to initiate metabolic and physiological processes without radicle emergence (Heydecker et al., 1975). Finnerty et al. (1992) found that priming en-

Received for publication 26 Feb. 1994. Accepted for publication 24 Mar. 1994. Journal article no. 13292. The Ohio Agricultural Research and Development Center, The Ohio State Univ. Mention of a trademark, proprietary product, or vendor does not constitute a product guarantee or warranty by The Ohio State Univ. and does not imply its approval to the exclusion of other products or vendors that also may be suitable. The cost of publishing this paper was defrayed in part by the payment of page charges. Under postal regulations, this paper therefore must be hereby marked advertisement solely to indicate this fact.

${ }^{1}$ Former Graduate Research Associate.

${ }^{2}$ Associate Professor and State Extension Specialist-Vegetable Crops.

${ }^{3}$ Professor of Horticulture. hanced germination percentage of the herbaceous perennials Aquilegia caerulea $\mathrm{L}$. and A.canadensis L. As the priming duration increased for A. caerulea, so did the final percent germination.

The objectives of this study were to determine 1) the germination of $R$. fulgida seeds primed at various osmotic potentials of PEG 8000 or potassium nitrate at the defined optimum germination temperature (Fay et al., $1993 \mathrm{~b}$ ) and 2) the germination rate and total percent germination of osmotically primed $R$. fulgida seeds over a temperature gradient using a selected priming regime.

\section{Materials and Methods}

Osmoticum and osmotic potential. After determining the optimum germination temperature for $R$. fulgida (Fay et al., 1993b), preliminary studies were conducted to determine optimum osmotic seed priming conditions in aerated solutions. As Akers and Holley (1986) indicated, germination tests should be performed before priming to determine the osmotic agent, potential temperature of the osmoticum, and priming duration. Priming duration is defined (Akers and Holley, 1986) as the time necessary to reach a germination percentage plateau in aerated water. To determine the optimum priming duration, four replications of 100 seeds each from a low-vigor seedlot (Fay et al., 1993a) were hydrated in $100 \mathrm{ml}$ of aerated distilled water at $30 \pm 1 \mathrm{C}$. Germination plateaued at $51 \%$ after 7 days. Thus, the duration of seed priming was established as 7 days (Akers and Holley, 1986).

Three replications of 50 seeds each were primed at $30 \pm 1 \mathrm{C}$ for 7 days in solutions of potassium nitrate $\left(\mathrm{KNO}_{3}\right)$ or PEG 8000 at five osmotic potentials; for $\mathrm{KNO}_{3}$, they were -0.6 , $-0.8,-1.0,-1.3$, or $-1.5 \mathrm{MPa}$ prepared, respectively, by adding $9.5,16.0,22.0,30.5$, or $35.0 \mathrm{~g} \mathrm{KNO}_{3} /$ liter of double-distilled water. Osmotic potentials for PEG 8000 were -0.5 , $-0.7,-1.0,-1.3$, or $-1.6 \mathrm{MPa}$ prepared, respectively, by adding $180,250,300,350$, or
400 g PEG 8000/liter of double-distilled water. Osmotic potentials were determined using a SC-10 thermocouple psychrometer (Decagon, Pullman, Wash.).

Seeds were primed in 4-cm-diameter polyvinyl chloride columns containing $100 \mathrm{ml}$ of the prepared solutions (Akers and Holley, 1986). Temperature of the osmotica was maintained by using a thermostatically controlled aquarium heater in the water surrounding the columns. Columns were refilled with the osmotic agent as needed. Each 50-seed replication was contained in a nylon mesh bag to prevent seeds from adhering to the sides of the columns. After 7 days, seeds were taken from the priming solutions and rinsed thoroughly under running distilled water for at least $5 \mathrm{~min}$. Mean germination during priming was $26 \%$ for $-0.6 \mathrm{MPa} \mathrm{KNO}_{3}, 2 \%$ for $-0.8 \mathrm{MPa} \mathrm{KNO}_{3}$, $1.0 \%$ for $-1.0 \mathrm{MPa} \mathrm{KNO}_{3}$, and $4 \%$ for -0.5 MPa PEG 8000. Seeds then were blotted dry and placed under a laminar flow hood for $24 \mathrm{~h}$ to dry. Seeds of each replication were placed on a 8.7-cm-diameter blue blotter circle (Anchor Paper, St. Paul, Minn.) in $100 \times 15-\mathrm{mm}$ polystyrene petri dishes. The seeds then were germinated at $30 \pm 1 \mathrm{C}$ in a germinating chamber-7 days for $\mathrm{KNO}_{3}$ treatments and 9 days for PEG 8000. Total percent germination and mean time of germination (MTG) (Rivas et al., 1984) were calculated for each priming treatment: $\mathrm{MTG}=\mathrm{T}_{1} \mathrm{~N}_{1}+\mathrm{T}_{2} \mathrm{~N}_{2}+\ldots+\mathrm{T}_{\mathrm{n}} \mathrm{N}_{\mathrm{n}}$ )/total number of seeds germinated; where $\mathrm{T}=$ day number (test initiated on day 0 ) and $\mathrm{N}=$ number of seeds germinated.

Germination response to temperature. Four replications of 50 seeds each were primed (-1.3 $\mathrm{MPa} \mathrm{KNO}_{3}, 30 \mathrm{C}$ for 7 days) and dried as described for the first study. These seeds and four replications of 50 nonprimed seeds were germinated in darkness at $32.2,30.5,28.8$, $27.6,26.1,24.9,23.4,21.9,20.2$, or $18.8 \pm$ $0.1 \mathrm{C}$ on a thermogradient table (Type DB 2000; van Dok \& de Boer, Enkhuizen, NL). Total percentage and MTG were determined as described above.

\section{Results and Discussion}

Osmoticum and osmotic potential. Total percent germination increased linearly with decreasing osmotic potential of $\mathrm{KNO}_{3}$ from $68 \%$ at $-0.6 \mathrm{MPa}$ to $\geq 90 \%$ at $-1.0 \mathrm{MPa}$ or lower, but MTG was unaffected (Table 1). The highest osmotic potential of $\mathrm{KNO}_{3}(-0.6 \mathrm{MPa})$ resulted in excessive germination $(26 \% \pm 8.7 \%)$ during priming. Decreasing osmotic potential of PEG 8000 resulted in a linear decrease in total percent germination and a linear increase in MTG (Table 1). The lower total percent germination and longer MTG of PEG-primed seeds compared to $\mathrm{KNO}_{3}$-primed seeds may be attributed to lower $\mathrm{O}_{2}$ availability in PEG 8000 (Mexal et al., 1975) or to decreased seed hydration (Alvarado and Bradford, 1988). The highest total germination percentage achieved with PEG-primed seeds (82\%) was less than that achieved with $-1.3 \mathrm{MPa} \mathrm{KNO}_{3}(95 \%)$. Compared to nonprimed seeds, seeds primed in $-1.3 \mathrm{MPa} \mathrm{KNO}_{3}$ had double the total percent germination and one-half the MTG. 
Table 1. Total percent germination and mean time of germination (MTG) of Rudbeckia fulgida seeds at 30C after priming ( 7 days, $30 \pm 1 \mathrm{C}$ ) at various osmotic potentials of $\mathrm{KNO}_{3}$ or polyethylene glycol (PEG) 8000 .

\begin{tabular}{|c|c|c|c|}
\hline \multirow[b]{2}{*}{ Osmoticum } & \multirow{2}{*}{$\begin{array}{c}\text { Osmotic } \\
\text { potential } \\
(\mathrm{MPa})\end{array}$} & \multicolumn{2}{|c|}{ Germination } \\
\hline & & $\begin{array}{c}\text { Total } \\
(\%)\end{array}$ & $\begin{array}{r}\text { MTG } \\
\text { (days) }\end{array}$ \\
\hline None & --- & 48 & 5.9 \\
\hline \multirow[t]{5}{*}{$\mathrm{KNO}_{3}$} & -0.6 & 68 & 2.9 \\
\hline & -0.8 & 85 & 2.8 \\
\hline & -1.0 & 90 & 2.8 \\
\hline & -1.3 & 95 & 3.0 \\
\hline & -1.5 & 91 & 3.1 \\
\hline \multirow[t]{5}{*}{ PEG } & -0.5 & 82 & 3.2 \\
\hline & -0.7 & 75 & 4.1 \\
\hline & -1.0 & 63 & 4.4 \\
\hline & -1.3 & 53 & 5.4 \\
\hline & -1.6 & 47 & 6.0 \\
\hline LSD $_{0.05}(1-$ way $)$ & & 20.3 & 0.9 \\
\hline \multicolumn{4}{|l|}{$\mathrm{F}$ test significances } \\
\hline Osmoticum (OS) & & ** & ** \\
\hline Osmotic potential (OP) & & NS & ** \\
\hline $\mathrm{OS} \times \mathrm{OP}$ & & ** & ** \\
\hline $\mathrm{KNO}_{3}$ linear & & ** & NS \\
\hline $\mathrm{KNO}_{3}$ quadratic & & NS & NS \\
\hline PEG linear & & $* *$ & ** \\
\hline PEG quadratic & & NS & NS \\
\hline
\end{tabular}

Ns, ** Nonsignificant or significant at $P \leq 0.01$, respectively.

Germination response to temperature. Total percent germination of primed $(-1.3 \mathrm{MPa}$ $\mathrm{KNO}_{3}, 30 \mathrm{C}$ for 7 days) and nonprimed seeds increased quadratically with increasing temperature, but primed seeds had higher total percent germination than nonprimed seeds at $\geq 21.9 \mathrm{C}$ (Table 2). Priming also increased germination rate. The MTG of primed seeds was an average 2.3 days (43\%) lower than that of nonprimed seeds between 24.7 and $32.2 \mathrm{C}$ (Table 2). Although MTG varied within this temperature range, the 0.8 -day range for primed seeds and 1.2-day range for nonprimed seeds was too small to be of practical significance.

Since the highest total germination percentage of nonprimed seeds occurred at 28.8 to $32.2 \mathrm{C}$ (Table 2 ), which agrees with $30 \pm 1 \mathrm{C}$ from Fay et al. (1993b), the upper germination temperature recommended in germination guides (Nau, 1989) or seed catalogs (George J.
Ball, 1989; G.W. Park Seed Co., 1989-90) for $R$. fulgida should be increased.

Osmotic priming lowered the temperature at which germination was high (Table 2). Such an improvement in germination percentage at low temperatures in response to seed priming has been noted for other species (Carpenter and Boucher, 1991; Pill et al., 1991; Sachs, 1977). Although the total germination percentage of primed or nonprimed seeds was not decreased at the highest germination temperatures relative to lower ones (Table 2), seed priming has increased high-temperature germination percentage of certain species (Atherton and Farooque, 1983; Carpenter and Boucher, 1991; Valdes and Bradford, 1987).

The moisture content of seeds (four replications of 50 seeds each, $104 \mathrm{C}$ for $48 \mathrm{~h}$ ) immediately following priming in $-1.3 \mathrm{MPa}$ $\mathrm{KNO}_{3}$ for 7 days at $30 \mathrm{C}$ was $24.7 \% \pm 1.7 \%$,

Table 2. Germination percentage and mean time of germination (MTG) of primed and nonprimed Rudbeckia fulgida seeds as influenced by germination temperature.

\begin{tabular}{|c|c|c|c|c|}
\hline \multirow{3}{*}{$\begin{array}{l}\text { Germination } \\
\text { temp (GT) } \\
\left({ }^{\circ} \mathrm{C}\right)\end{array}$} & \multicolumn{4}{|c|}{ Seed treatment (ST) } \\
\hline & Primed & Nonprimed & Primed & Nonprimed \\
\hline & \multicolumn{2}{|c|}{ Total germination $(\%)$} & \multicolumn{2}{|c|}{ MTG (days) ${ }^{z}$} \\
\hline 18.8 & 0 & 0 & --- & --- \\
\hline 20.2 & 5 & 0 & --- & --- \\
\hline 21.9 & 13 & 0 & 3.5 & --- \\
\hline 23.3 & 33 & 1 & 3.0 & --- \\
\hline 24.7 & 66 & 6 & 3.2 & 6.1 \\
\hline 26.1 & 85 & 21 & 3.2 & 4.9 \\
\hline 27.6 & 95 & 50 & 2.8 & 5.0 \\
\hline 28.8 & 93 & 70 & 2.9 & 5.2 \\
\hline 30.5 & 94 & 77 & 3.0 & 5.6 \\
\hline 32.2 & 92 & 72 & 3.6 & 5.8 \\
\hline $\mathrm{LSD}_{0.05}(2-w a y)$ & \multicolumn{2}{|c|}{8.4} & \multicolumn{2}{|c|}{0.6} \\
\hline \multicolumn{5}{|l|}{ F test significances } \\
\hline GT & \multicolumn{2}{|c|}{$* *$} & \multicolumn{2}{|c|}{$* *$} \\
\hline ST & \multicolumn{2}{|c|}{$* *$} & \multicolumn{2}{|c|}{$* *$} \\
\hline $\mathrm{GT} \times \mathrm{ST}$ & \multicolumn{2}{|c|}{$* *$} & \multicolumn{2}{|c|}{$* *$} \\
\hline GT linear & $* *$ & $* *$ & $* *$ & NS \\
\hline GT quadratic & $* *$ & $* *$ & $* *$ & NS \\
\hline
\end{tabular}

${ }^{z_{---}}=$Low germination percentage precluded calculation of MTG

ss, ** Nonsignificant or significant at $P \leq 0.01$, respectively. while after drying for $48 \mathrm{~h}$ in a laminar flow hood (air flow rate $=1800 \mathrm{~m} \cdot \mathrm{s}^{-1}$ ), it was $16.0 \%$ $\pm 2.7 \%$. Thus, primed seeds were able to pass through phase I imbibition more rapidly than nonprimed seeds (moisture $=6.6 \% \pm 0.6 \%$ ) Accumulation of solutes, enzyme activation, and initiation of metabolic events during controlled seed imbibition (Bewley and Black, 1978) contributed to the increased radicle emergence rate of the primed seeds.

The $R$. fulgida seedlot used in this study had displayed low vigor as monitored by accelerated aging, low-temperature, and conductivity tests (Fay et al., 1993a). Since germination of this seedlot increased $7 \%$ by priming in $-1.3 \mathrm{MPa} \mathrm{KNO}_{3}$ (30C for 7 days) following 1 year storage at $23 \mathrm{C}$ in sealed plastic containers, priming enhanced the germination of this low-vigor seedlot, a response noted in lowvigor carrot (Daucus carota) seeds (Szafirowska et al., 1981).

The results of this study show that osmotic priming of Rudbeckia fulgida seed in -1.3 $\mathrm{MPa} \mathrm{KNO}_{3}$ for 7 days at $30 \mathrm{C}$ increased their germination rate and percentage at 21.9 to 32.2C. PEG was not a satisfactory priming osmoticum for this species. Germination of primed and nonprimed seeds is optimal between 28 and $32 \mathrm{C}$.

\section{Literature Cited}

Akers, S.W. and K.E. Holley. 1986. SPS: A system for priming seeds using aerated polyethylene glycol or salt solutions. HortScience 21:529531.

Alvarado, A.D. and K.J. Bradford. 1988. Priming and storage of tomato (Lycopersiconlycopersum) seeds. I. Effects of storage of temperature on germination rate and viability. Seed Sci. \& Technol. 16:601-612.

Association of Official Seed Analysts. 1990. Rules for testing seeds. J. Seed Technol. 12:1-72.

Atherton, J.G. and A.M. Farooque. 1983. High temperature effects in spinach. II. Effects of osmotic priming. Scientia Hort. 19:221-227.

Bewley, J.D. and M. Black. 1978. Physiology and biochemistry of seeds in relation to germination: Development, germination, and growth. vol. 1. Springer-Verlag, New York.

Brocklehurst, P.A. and J. Dearman. 1984. A comparison of different chemicals for osmotic treatment of vegetable seed. Ann. Applied Biol. 105:391-398.

Carpenter, W.J. and J.F. Boucher. 1991. Priming improves high-temperature germination of pansy seed. HortScience 26:541-544.

Fay, A.M., M.B. McDonald, Jr., and S.M. Still. 1993a. Seed vigor testing of Rudbeckia fulgida. Seed Sci. \& Technol. 21:453-462.

Fay, A.M., S.M. Still, and M.A. Bennett. 1993b. Optimum germination temperature of Rudbeckia fulgida. HortTechnology 3:433-435.

Finnerty, T.L., J.M. Zajicek, and M.A. Hussey. 1992. Use of seed priming to bypass stratification requirements of three Aquilegia species. HortScience 27:310-313.

George J. Ball. 1989. Ball seed catalog. G.J. Ball, Chicago.

G.W. Park Seed Co. 1989-90. Park seed wholesale catalog. G.W. Park Seed Co., Greenwood, S.C.

Heydecker, W. and P. Coolbear. 1977. Seed treatments for improved performance-survey and attempted prognosis. Seed Sci. \& Technol. 5:353-425. 


\section{Crop Production}

Heydecker, W., J. Higgins, and Y.J. Turner. 1975. Invigoration of seeds? Seed Sci. \& Technol. 3:881-888.

Mexal, J., J.T. Fisher, J. Osteryoung, and C.P. Reid. 1975. Oxygen availability in polyethylene glycol solutions and its implications in plant-water relations. Plant Physiol. 55:20-24.

Nau, J. 1989. Ball culture guide-The encyclopedia of seed germination. G.J. Ball, Chicago.

Pill, W.G., J.J. Frett, and D.C. Morneau. 1991.
Germination and seedling emergence of primed tomato and asparagus seeds under adverse conditions. HortScience 26:1160-1162.

Rivas, M., F.J. Sundstrom, and R.L. Edwards. 1984. Germination and crop development of hot pepper after seed priming. HortScience 19:279-281.

Sachs, M. 1977. Priming of watermelon seeds for low-temperature germination. J. Amer. Soc. Hort. Sci. 102:175-178

Szafirowska, A., A.A. Khan, and N.H. Peck. 1981.
Osmoconditioning of carrot seeds to improve seedling establishment and yield in cold soil. Agron. J. 73:845-848.

Tayama, H.K. (ed.). 1989. Tips on growing potted perennials and biennials. Ohio Coop. Ext. Serv. Bul. FP-766, The Ohio State Univ., Columbus.

Valdes, V.M. and K.J. Bradford. 1987. Effects of seed coating and osmotic priming on the germination of lettuce seeds. J. Amer. Soc. Hort. Sci. 112:153-156. 